\title{
On the last mosasaurs: Late Maastrichtian mosasaurs and the Cretaceous-Paleogene boundary in New Jersey
}

\author{
William B. GALLAGHER ${ }^{1}$, KenNeth G. MILLER ${ }^{2}$, ROBERT M. SHERRELL ${ }^{2}$, JAMES V. BROWNING ${ }^{2}$, \\ M. PAUL FIELD ${ }^{2}$, RICHARD K. OLSSON ${ }^{2}$, PETER J. SUGARMAN ${ }^{3}$, STEVEN TUORTO ${ }^{2}$ \\ and HENDRA WAHYUDI ${ }^{2}$
}

Key-words. - Mosasaurs, Cretaceous-Paleogene boundary, Iridium.

\begin{abstract}
New data regarding the placement of the Cretaceous-Paleogene (K/Pg) boundary in New Jersey is presented based on a recent campaign of drill coring boundary sections in the Atlantic coastal plain of southern New Jersey. The occurrence of late Maastrichtian mosasaurs worldwide and in New Jersey is reviewed in light of the continuing controversy over the rate and cause of the extinction at the K/Pg boundary. At the Meirs Farm site in Monmouth County, NJ, the biostratigraphic position of mosasaur specimens (Halisaurus platyspondylus, Mosasaurus hoffmann) is related to the occurrence of an iridium excursion of $0.5 \mathrm{ppb}$ ( $5 \mathrm{x}$ background levels) in the basal Hornerstown Formation just above the upper Maastrichtian New Egypt Formation. Other specimens in museum collections obtained during the acme of nineteenth century marl mining are from this area of the Maastrichtian outcrop belt in New Jersey. It is concluded that late Maastrichtian mosasaurs show no diminution of their biogeographic ranges and are not particularly rare in New Jersey in comparison to older mosasaur faunas. Mosasaurs became extinct in association with the collapse of the marine food web at the K/Pg boundary, and were replaced as apical marine predators in the early Danian by a variety of crocodilians.
\end{abstract}

\section{Les derniers mosasaures : les mosasaures du Maastrichtien supérieur et la limite Crétacé-Paléogène dans le New Jersey}

\begin{abstract}
Mots-clés. - Mosasaures, Limite Crétacé-Paléogène, Iridium
Résumé. - De nouvelles données concernant la position de la limite Crétacé-Paléogène (K/Pg) dans le New Jersey sont présentées ; elles sont basées sur une récente campagne de forages de limite de coupes dans la plaine côtière atlantique du Sud du New Jersey. La présence mondiale et dans le New Jersey de mosasaures d'âge maastrichtien supérieur est révisé à la lumière de la controverse toujours d'actualité sur les taux et causes de l'extinction de la limite K/Pg. Au lieu dit "Meirs Farm" dans le Comté de Monmouth, NJ, la position biostratigraphique de spécimens de mosasaures (Halisaurus platyspondylus, Mosasaurus hoffmanni) est liée à la présence d'une excursion d'iridium de $0.5 \mathrm{ppb}$ (5x niveau de fond) à la base de la formation Hornerstown, juste au dessus de la formation New Egypt d'âge maastrichtien supérieur. D'autres spécimens conservés dans des musées récoltés durant l'acmé de l'exploitation minière des marnes au dix-neuvième siècle proviennent de cette ceinture d'affleurement du Maastrichtien dans le New Jersey. Il est conclu que les mosasaures du Maastrichtien supérieur ne montrent pas de baisse de leur distribution biogéographique et ne sont pas particulièrement rares dans le New Jersey, comparés aux faunes de mosasaures plus anciennes. Les mosasaures se sont éteints en relation avec l'effondrement de la chaîne alimentaire marine à la limite $\mathrm{K} / \mathrm{Pg}$, et ces mégaprédateurs ont été remplacés dans le Danien inférieur par une variété de crocodiliens.
\end{abstract}

\section{INTRODUCTION}

An oft-cited gradulist explanation for the extinction of Late Cretaceous marine vertebrates invokes widespread regression of epicontinental seas during the Maastrichtian and the concomitant shrinking of marine habitats, leading to mosasaur extinction well before the K/Pg boundary [Sullivan, 1989; Hallam and Wignall, 1997; Archibald et al., 2010]. One possible way to test this hypothesis is to look at the latest Cretaceous fossil record of mosasaurs, large marine squamates that were apical predators in Late Cretaceous marine ecosystems. If mosasaurs were endangered and gradually driven into extinction before the end-Cretaceous Chicxulub asteroid impact, then we would expect to see a diminution of their abundance, a decrease in diversity, and shrinkage of their biogeographic range well before the $\mathrm{K} / \mathrm{Pg}$ boundary. Here for the purposes of this study we will take the Late Maastrichtian to mean the last half of the stage, or the last several million years of the Cretaceous. This study will review the literature on global Late Maastrichtian mosasaur biogeography, then look at the specific stratigraphic distribution of Late Maastrichtian mosasaurs in New Jersey particularly with respect to a new program of coring $\mathrm{K} / \mathrm{Pg}$ deposits and establishing the stratigraphic

1. Department of Geological, Environmental and Marine Sciences, Rider University, Lawrenceville, NJ 08468 USA, wgallagher@rider.edu

2. Department of Earth and Planetary Sciences, 610 Taylor Road, Rutgers University, Piscataway, NJ 08854 kgm@rci.rutgers.edu;

3. New Jersey Geological Survey, PO Box 427, Trenton, NJ 08625, USA, Pete.Sugarman@dep.state.nj.us

Manuscript received on October 8, 2010; accepted on June 30, 2011. 
relationships of fossil faunas to geochemical anomalies and events at the end of the Mesozoic and the beginning of the Cenozoic Eras.

\section{GLOBAL DISTRIBUTION OF LATE MAASTRICHTIAN MOSASAURS}

Late Maastrichtian mosasaurs are known from numerous localities in northern Europe, North America, South America, Africa, New Zealand and Antarctica.

In Europe, upper Maastrichtian marine deposits yield mosasaur remains in the stratotype area of Maastricht in the southern Netherlands, and in nearby beds in Belgium [Jagt et al., 2008; Mulder et al., 1998]. In Denmark the white chalks at Stevns Klint have yielded Mosasaurus and Plioplatecarpus [Lindgren and Jagt, 2005]. Elsewhere, in eastern Europe, upper Maastrichtian mosasaur fossils are known from the Wisla valley of Poland [Machalski et al., 2003].

In the southern Hemisphere, Upper Cretaceous beds of New Zealand contain mosasaur fossils. Some mosasaur material from Seymour Island and Vega Island in the Antarctic Peninsula is late Maastrichtian [Martin, 2006]. Mosasaur specimens are known from $1.5 \mathrm{~m}$ and $3.5 \mathrm{~m}$ below the K/Pg boundary in northern Patagonia [Fernandez, Martin and Casadio, 2008]. In southern Africa, the "Skeleton Coast" of Angola has an abundance of mosasaur specimens, including some from upper Maastrichtian beds [Jacobs et al., 2009; Polcyn et al., 2010; M. Polcyn, personal communication, 2011]. Northern Africa has produced upper Maastrichtian mosasaurs from the phosphate beds of Morocco [Bardet et al., 2005]

In North America, the Timber Creek Member of the Fox Hills Formation in North Dakota has produced fragmentary mosasaur material of late Maastrichtian age [Hoganson et al., 2007]. Fragmentary mosasaur remains have been reported from the uppermost Cretaceous in Missouri, in what has been interpreted as a $\mathrm{K} / \mathrm{Pg}$ event bed [Gallagher et al., 2007]. Mosasaur material is known from the highest (youngest) ammonite zone of the uppermost Cretaceous in New Jersey [Gallagher, 2005], and upper Maastrichtian mosasaur fossils have been documented in Alabama [Kiernan, 2003].

\section{THE K/PG BOUNDARY IN NEW JERSEY}

Recent work on the uppermost Cretaceous deposits in New Jersey has established that the stratigraphically highest levels of the Cretaceous are latest Maastrichtian [Landman et al., 2004, 2007], and the K/Pg boundary ejecta layer has been located down dip in the subsurface in the Bass River core, marked by elevated iridium (Ir) levels, shocked quartz, and spherules (altered microtektites) [Olsson et al., 1997] just above the major extinction in Cretaceous planktonic foraminifera at a thin clay clast layer 1260 feet (384 m) below the surface. Since the initial report of an Ir anomaly at the $\mathrm{K} / \mathrm{Pg}$ boundary in Bottacione Gorge, Umbria, Italy [Alvarez et al., 1980], this evidence has been interpreted as supportive of the proposal that a large asteroid collided with Earth 65.5 million years ago, ending the Mesozoic Era.

We report here on a drilling program to establish the $\mathrm{K} / \mathrm{Pg}$ boundary in shallower up-dip sections correlated with outcrop stratigraphy and paleontology [Miller et al., 2010]. Why drill? Drilling offers a number of advantages in areas of limited exposure such as the New Jersey Atlantic coastal plain:

- Subsurface cores present a longer, more complete and continuous stratigraphic record than the thin outcrops available in most of the Atlantic Coastal Plain.

- Core samples are less weathered and less geochemically altered than surface outcrops and preservation of calcareous microfossils is usually better than in outcrop, which may be leached of carbonate.

- Coring of the K/Pg boundary in updip sections allows direct comparison with outcrop stratigraphy and paleontology, especially macrofossils.

- Coring of the K/Pg extinction allows delineation of the relationship of Ir excursions to latest Cretaceous- early Paleogene fossil assemblages.

We selected seven sites located in the updip outcrop belt of upper Maastrichtian- Paleogene sedimentary units, and cored 10 holes. This was accomplished by the United States Geological Survey Drilling Division, using a truck mounted drill-stabilized continuous core auger system. Core recovery from this drilling technology is accomplished by augering with a Lucite tube in the center of the hollow drilling auger that prevents core mixing and assures continuous core recovery.

Several sites that were drilled produced an Ir excursion, including the Meirs Farm site. The core here produced an anomaly of $0.5 \mathrm{ppb}$ Ir (elevated $5 x$ over background) at the base of the Hornerstown Formation [Miller et al., 2010] (see fig. 1), from above the top of the New Egypt/Red Bank depositional sequence (see table I for stratigraphic terminology).

In the latter part of the nineteenth century John Meirs operated the Cream Ridge Marl Company here, consisting of extensive marl pit excavations on the south end of the farm that dug down into the Hornerstown and New Egypt formations [Baird, 1984, 1986]. The Meirs Farm locality

TABLE I. - Stratigraphy of the Upper Cretaceous - Paleocene section in the Atlantic Coastal Plain of New Jersey.

TABL. I. - Stratigraphie de la coupe du Crétacé supérieur-Paléocène de la plaine côtière atlantique dans le New Jersey.

\begin{tabular}{|l|l|l|}
\hline Geochronology & Formation & Lithology \\
\hline Paleocene- Dano-Montian & Vincentown Formation & Quartz sand, limesand \\
\hline Paleocene- Danian, K/Pg & Hornerstown Formation & Glauconite sand \\
\hline Cretaceous- Maastrichtian & New Egypt Formation & Glauconitic clay \\
\hline Cretaceous- Maastrichtian & Tinton Formation & Glauconitic sandstone \\
\hline Cretaceous- Maastrichtian & Red Bank Formation & Quartz sand \\
\hline
\end{tabular}




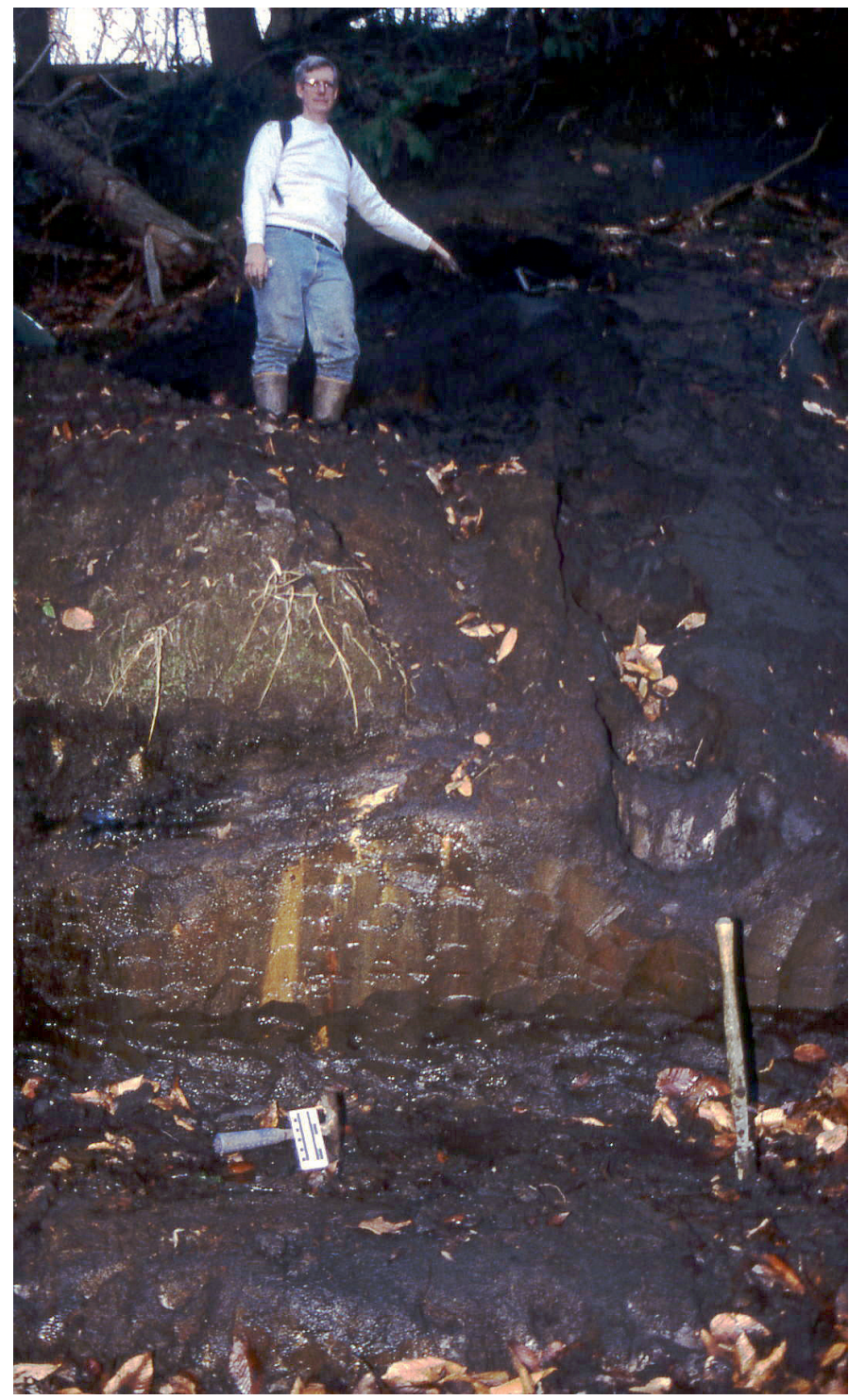

FIG. 1. - Late Maastrichtian-Early Danian section at Meirs Farm site, Cream ridge, Monmouth County, NJ. The person is standing in front of the Paleogene Hornerstown Formation, with his boots on the contact with the underlying Late Cretaceous New Egypt Formation, at approximately the location of the Ir excursion. The string of Mosasaurus vertebrae (MAPS 1233a) was excavated from the level where the spade handle is visible on the left side of the photograph.

FIG. 1. - Coupes du Maastrichtien supérieur-Danien inférieur au lieu dit "Meirs Farm », Cream ridge, Comté de Monmouth, NJ. Le personnage se tient devant la formation Hornerstown d'âge paléogène, avec ses bottes au contact avec la formation New Egypt sous-jacente d'âge crétacé supérieur, à peu près à l'endroit de l'excursion d'iridium. La série de vertèbres de Mosasaurus (MAPS 1233a) a été trouvée dans le niveau où se trouve le manche de marteau à gauche sur la photo.

has historically been a source of fossil specimens for O. C. Marsh and others. Marsh [1869] named Halisaurus platyspondylus, H. fraternus, Mosasaurus meirsi (based on a tooth), and $M$. princeps from the marl pits in the $\mathrm{K} / \mathrm{Pg}$ section here. Russell [1967] synonymized $M$. princeps with $M$. maximus (and thus by extension $M$. hoffmanni). $H$. fraternus is a junior synonym of $H$. platyspondylus. A plesiosaur coracoid was also reported from here [Baird, 1984].
More recently a string of seven mosasaur anterior caudal vertebrae have been excavated from stream bank outcrops on the farm (MAPS 1233a). These specimens can be placed in stratigraphic context with respect to the $\mathrm{K} / \mathrm{Pg}$ boundary and the Ir excursion. The vertebrae are assigned to Mosasaurus cf. hoffmanni. They were excavated from a level 3.5 meters below the contact between the New Egypt Formation and the Hornerstown Formations; the level of the iridium anomaly in the core was at this contact. So the mosasaur vertebrae were found $3.5 \mathrm{~m}$ below the level of the Ir excursion. They are associated with a marine invertebrate fauna consisting of the ammonite Eubaculites carinatus and the bivalves Cucullaea vulgaris and Pecten venustus.

The older collections of mosasaur material that were obtained from the extensive marl mines in New Jersey contain specimens from the outcrop belt of the upper Maastrichtian New Egypt Formation. This formation was known informally as the "chocolate marl" to the marl pit workers of the nineteenth century. Careful review of older collections shows that some of the mosasaur material from New Jersey described by Leidy, Cope and Marsh and reposited in the Academy of Natural Sciences of Philadelphia (ANSP), the American Museum of Natural History and the Yale Peabody Museum was obtained from sites within the outcrop area of the upper Maastrichtian marl beds. As an example, specimens in the ANSP collection from Lumberton, Pemberton, Medford and Vincentown in Burlington County are from old marl mines that penetrated upper Maastrichtian New Egypt beds. In addition, more recent collecting efforts have produced stratigraphically controlled specimens. For instance, a specimen of Prognathodon rapax (New Jersey State Museum \# 9827) is from the New Egypt Formation at the Inversand Pit in Sewell $\mathrm{NJ}$, as are two skulls of Mosasaurus hoffmanni (=M. maximus). Multi-element mosasaur specimens from the basal Hornertown Formation fossiliferous concentration are also well documented (ANSP \# 15679) [Gallagher, 1993]. Collecting efforts by private collectors, chief among which have been the collectors associated with the Monmouth Amateur Paleontological Society (MAPS), have also produced a number of partial specimens and isolated mosasaur bones and teeth from the upper Maastrichtian New Egypt beds of New Jersey [Gallagher, 2005].

\section{DISCUSSION}

While there may have been some small dimunition of diversity from earlier Maastrichtian faunas, late Maastrichtian mosasaurs were just as widespread and not particularly rare, at least in New Jersey, if compared to other older mosasaur faunas in this area [Gallagher, 2005]. For instance, mosasaur remains are more common in New Jersey upper Maastrichtian deposits than in the Santonian-Lower Campanian Merchantville Formation of New Jersey [Gallagher, 2005]; although this is not the case elsewhere (Gulf Coast, Western Interior), this pattern may merely reflect available outcrop area. Close relationships between mosasaur populations across the Atlantic [Mulder, 1999] and into the Western Interior suggest wide biogeographic ranges for these large predators, also a characteristic observable in modern large marine predators [Gallagher, 2005]. 


\section{Meirs Farm 1}

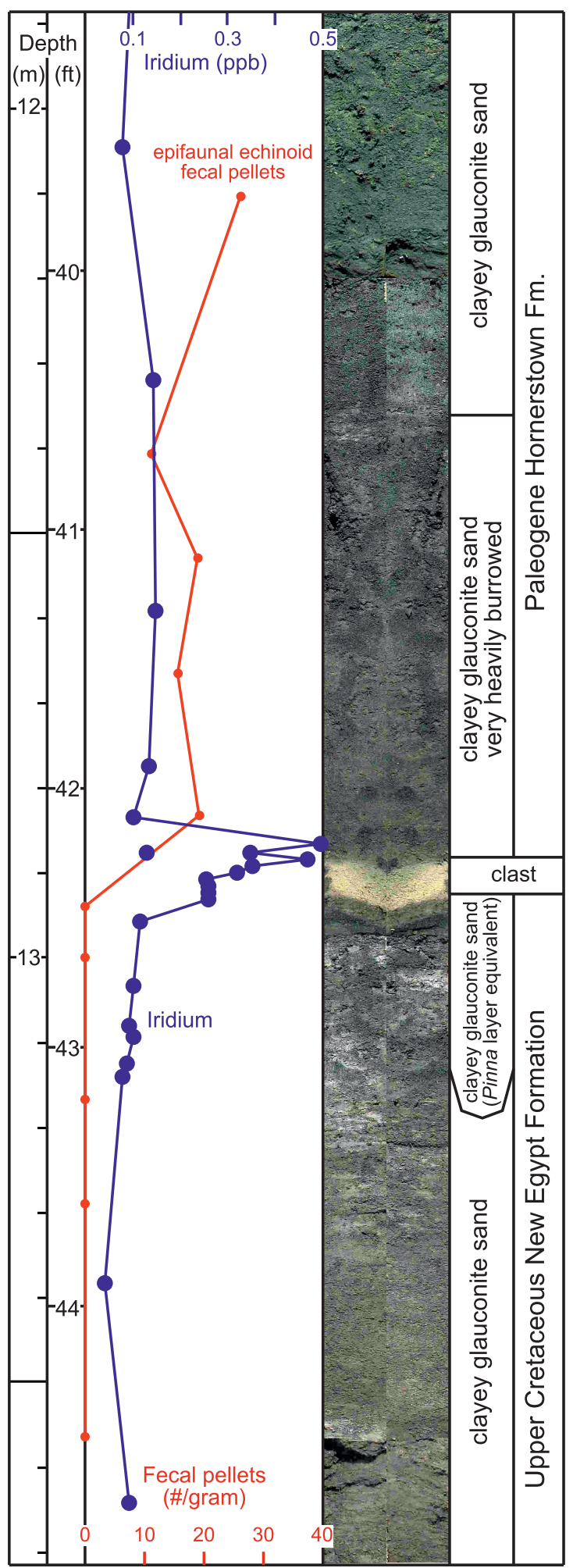

FIG. 2. - Ir in parts per billion (ppb), fecal pellets in number/grams of sediment, core photograph, lithology, and formational assignment for the Meirs Farm $1\left(40^{\circ} 06\right.$ ' $15.48 " \mathrm{~N}, 74^{\circ} 31^{\prime} 37.48$ " W) corehole. After Miller et al. [2010].

FIG. 2. - Iridium en millionième ( $p p b$ ), boulettes fécales en nombre/gramme de sédiment, photographie de la carotte, lithologie et nom des formations pour la carotte de forage du lieu dit "Meirs Farm 1 » (40 06' 15.48" N, 74 31' 37.48” W). D'après Miller et al. [2010].
In New Jersey, locality data for specimens collected in the 19th century in collections of the Academy of Natural Sciences of Philadelphia, the American Museum of Natural History, and the Yale Peabody Museum show that many of these specimens came from the outcrop belt of the uppermost Cretaceous New Egypt Formation that has an Ir excursion at top at Meirs Farm and other sites (Bass River, Search Farm, Buck Pit) [Miller et al., 2010]. More recent work has established that the stratigraphically highest mosasaur remains in this section, primarily Mosasaurus cf. hoffmanni specimens from the basal fossiliferous layer of the Hornerstown Formation [Gallagher, 1993, 2005] are associated with an Ir excursion an order of magnitude above background levels, with a $\mathrm{Pt} / \mathrm{Ir}$ ratio of 1.35 that indicates an extraterrestrial source, in a drill core taken at the Inversand Pit in Gloucester County, NJ [Gallagher et al., 2011].

Mosasaurus, Prognathodon, and Halisaurus are the late surviving mosasaur genera currently recognized in New Jersey. Of these Mosasaurus hoffmanni was the largest apical marine predator with estimated body lengths of 40 to 49 feet [Russell, 1967], Prognathodon rapax was an intermediate length shell and/or bone cruncher, and the plesiomorphic Halisaurus platyspondylus filled the niche of smaller shallow water predator occupied by Clidastes in the SantonianCampanian seas. This subdivision of ecological niches is similar to earlier mosasaurian faunas.

\section{CONCLUSIONS}

A fall in sea level during the Maastrichtian [Olsson et al., 2002] would have reduced shelf areas and marine habitat area. However, we suggest that mosasaurs could simply retreat into deeper waters and remain in those large areas still covered by the sea. Large scale regression and change in sea-level during the Pleistocene did not leave any trace of a major extinction among odontocetes, the best modern ecological analogue of mosasaurs. The disappearance of the mosasaurs is more probably linked to the collapse of the latest Cretaceous marine food webs as plankton populations crashed at the K/Pg boundary, driven by environmental and ecological effects of large bolide impact [Gallagher, 1993, 2002]. Direct evidence for this is the association of mosasaur specimens with the iridium anomalies located by the core-drilling campaign in the New Jersey coastal plain, especially the presence of a widespread Ir excursion in the basal Hornerstown Formation at the K/Pg boundary [Miller et al., 2010; Gallagher et al., 2011].

In New Jersey, mosasaurs were replaced as apical marine predators by a variety of crocodilians (Thoracosaurus, Hyposaurus, Diplocynodon, Bottosaurus) that radiated into marine niches and became more common in the early Danian [Gallagher, 1993, 2002, 2005]. Data from other areas such as Brazil [Barbosa, 2008] and Morocco [Jouve et al., 2008] corroborate this same pattern of ecological replacement.

The distribution of late Maastrichtian mosasaurs suggests that mosasaur populations were still widespread late into the last stage of the Mesozoic Era. This argues against the gradualist implication that mosasaurs disappeared as a 
result of global sea level fall and regression. The stratigraphic position of the mosasaur specimens at Meirs Farm and Inversand in relation to the Ir excursion supports the contention that the mass extinction of the Cretaceous fauna represented here at the $\mathrm{K} / \mathrm{Pg}$ boundary was due to the environmental effects of an asteroid impact, rather than a fauna surviving the K/Pg boundary only to go extinct afterwards [Landman et al., 2007]. The hypothesis that Cretaceous faunas survived the impact is based on identification of an uppermost Cretaceous fauna (the Pinna bed of Landman et al. [2007]) above the Ir excursion at the Tighe Park NJ locality. However, the Ir peak at this locality occurs at a permeability and porosity redox change and results from secondary geochemical mobilization and redeposition of an original Ir concentration higher in the section [Miller et al., 2010]. It is also possible that while some typically Cretaceous forms survived briefly after the boundary, continuing and protracted environmental deterioration (disruption of oceanic food chains, for example the so-called "Strangelove Ocean") led to ultimate extinction [Gallagher, 1993].
These are the initial results from an extensive program of coring in the Atlantic coastal plain deposits of New Jersey. Data from core sections taken at other sites in New Jersey await more geochemical and biostratigraphic analysis of $\mathrm{K} / \mathrm{Pg}$ core samples [Miller et al., 2010] and further research will be reported upon in future papers [Gallagher et al., 2011].

Acknowledgements. - We would like to thank all the people and organizations that cooperated in letting us drill on their properties, especially Dr. David Meirs of Walnridge Farm, and the Inversand Company of Pitman, NJ. Thanks to Ralph Johnson of the Monmouth Amateur Paleontological Society for allowing us access to specimens in the MAPS collection, and to Ted Daeschler of the Academy of Natural Sciences of Philadelphia for access to mosasaur specimens in his keeping. Funding for the K/Pg drilling project was made possible by NSF Grant \# 070778 to PI Kenneth Miller. We thank U.S.G.S. master driller Gene Cobb and his crew for their work bringing up the cores. Reviews of the manuscript by Michael J. Polcyn and Michael J. Everhart improved this paper, and we thank them for their suggestions.

\section{References}

Alvarez L., Alvarez W., Asaro F. \& Michel H. (1980). - Extraterrestrial cause for the Cretaceous-Tertiary extinction: experimental results and theoretical interpretations. - Science, 208, 1095-1108.

ArChibAlD D. plus 29 co-authors (2010). - Cretaceous extinctions: Mul tiple causes. - Science, 238, 973.

BAIRD D. (1984). - No ichthyosaurs in the Upper Cretaceous of New Jersey or Saskatchewan. - The Mosasaur, 2, 129-133.

BAIRD D. (1986). - Halisaurus and Prognathodon, two uncommon mosasaurs from the Upper Cretaceous of New Jersey. - The Mosasaur, 3, 37-45.

Barbosa J. A., Kellner A. W. A. \& Viana M. S. S. (2008). - New dryosaurid crocodylomorph and evidences for faunal turnover at the K-P transition in Brazil. - Proc. R. Soc. B, dol: 1098/rspb.2008.0110, 1-7.

Bardet N., Suberbiola X. P., Iarochene M., Amalik M. \& Bouya B. (2005). - Duraphagous Mosasauridae (Squamata) from the Upper Cretaceous phosphates of Morocco, with description of a new species of Globidens. - Neth. J. Geosci. (Geol. Mijnb.), 84, 3, 167-175.

Fernandez M., Martin J. \& Casadio S. (2008). - Mosasaurs (Reptilia) from the late Maastrichtian (Late Cretaceous) of northern Patagonia (Rio Negro, Argentina). - J. South Am. Earth Sci., 25 $176-186$

Gallagher W. (1993). - The Cretaceous-Tertiary mass extinction event in the northern Atlantic coastal plain. - The Mosasaur, 5, 75-154.

Gallagher W. (2002). - Faunal changes across the Cretaceous-Tertiary (K-T) boundary in the Atlantic coastal plain of New Jersey: Restructuring the marine community after the K-T mass extinction event. In: C. Koeberl \& K.G. Mackleod, Eds., Catastrophic events and mass extinctions: impacts and beyond. - Geol. Soc. Amer. Sp. Paper, 356, 291-301.

GALlagher W. (2005). - Recent mosasaur discoveries from New Jersey and Delaware, USA: stratigraphy, taphonomy, and implications for mosasaur extinction. - Neth. J. Geosci. (Geol. Mijnb.), 84, 241-245.

Gallagher W., Campbell C., Jagt J. \& Mulder E. (2007). - Mosasaur (Reptilia, Squamata) material from the Cretaceous-Tertiary boundary interval in Missouri. - J. Vert. Paleont., 25, 2, 473-475.
Gallagher W., Miller K.G., Sherrell R. M., Browning J. V., Field M. P., Olsson R. K., Sugarman P.J., Tuoto S. \& Wahyudi H. (2011). - Fossil vertebrate assemblages and iridium anomaly in the Cretaceous-Paleogene section of New Jersey. - Abstracts with Program, Northeast/North Central Geological Society of America Sectional Meeting, Pittsburgh, PA, 20-22 March 2011.

Hallam A. \& Wignall P. (1997). - Mass extinctions and their aftermath. Oxford University Press, Oxford U.K., 320 p.

Hoganson J., Erickson J. \& Holland F. (2007). - Amphibian, reptilian, and avian remains from the Fox Hills Formation of New Jersey: Shoreline and estuarine deposits in south-central North Dakota. In: J. MARTIN \& D. PARRIS, Eds, Geology and paleontology of the Late Cretaceous marine deposits of the Dakotas. - Geol. Soc. Amer. Spec. Paper, 427, 239-256.

Jacobs L., Polcyn M., Mateus O., Schulp A. \& Neto A. (2009). - The Cretaceous skeleton coast of Angola. - Program and abstracts for annual meeting, Bristol, England, Sept. 23-26, 2009. J. Vert. Paleont., 29, supplement to \#3, 121A.

Jagt J., Coronelissen D., Mulder E., Schulp A., Severijins J. \& Verdin L. (2008). - The youngest in situ record to date of Mosasaurus hoffmanni (Squamata, Mosasauridae) from the Maastrichtian type area, The Netherlands. - Proceedings of the Second Mosasaur Meeting. - Fort Hays Studies Special Issue 3, Fort Hays State University, Hays, Kansas, 73-80

Jouve S., Bardet N., Jalil N-E, Suberbiola X. P., Bouya B. \& Amaghaz M. (2008). - The oldest African crocodylian phylogeny, paleobiogeography, and differential survivorship of marine reptiles through the Cretaceous-Tertiary boundary. - J. Vert. Paleont., 28, 2, 409-421.

KIERNAN C. (2003). - Stratigraphic distribution and habitat segregation of mosasaurs in the Upper Cretaceous of western and central Alabama, with an historical review of Alabama mosasaur discoveries. - J. Vert. Paleont., 22, 1, 91-103.

LANDMAn N., Johnson R. \& Edwards L. (2004). - Cephalopods from the Cretaceous/Tertiary boundary interval on the Atlantic Coastal Plain with a description of the highest ammonite zones in North America. Part 2. Northeastern Monmouth County, New Jersey. Bull. Am. Mus. Nat. Hist., 287, 107 p. 
Landman N., Johnson R., Garb M., Edwards L. \& Kyte F. (2007). - Cephalopods from the Cretaceous/Tertiary boundary interval on the Atlantic Coastal Plain with a description of the highest ammonite zones in North America. Part 3. Manasquan River Basin, Monmouth County, New Jersey. - Bull. Am. Mus. Nat. Hist. 303, $122 \mathrm{p}$.

Lindgren J. \& JAGT J. (2005). - Danish mosasaurs. - Neth. J. Geosci. (Geol. Mijnb.), 84, 315-320.

Machalski M., Jagt J., Dortangs R., Mulder E. \& Radwanski A (2003). - Campanian and Maastrichtian mosasaurid reptiles from central Poland. - Acta Palaeont. Polonica, 48, 3, 397-408.

Marsh O. C. (1869). - Notice of some new mosasauroid reptiles from the Greensand of New Jersey. - Am. J. Sci., 48, 392-397.

MARTin J. (2006). - Biostratigraphy of the Mosasauridae (Reptilia) from the Cretaceous of Antarctica. In: J. Francis, D. Pirrie \& J. Crame, Eds., Cretaceous-Tertiary high latitude paleoenvironments, James Ross basin, Antarctica. - Geol. Soc. London Sp. Publ., 258, 101-108.

Miller K., Sherrell R., Browning J., Field M., Gallagher W., Olsson R., Sugaran P., TuOrTo S. \& WAHyudi H. (2010). - Relationship between mass extinction and iridium across the Cretaceous-Paleogene boundary in New Jersey. - Geology, 38, 867-870.

Mulder E. (1999). - Transatlantic latest Cretaceous mosasaurs (Reptilia, Lacertilia) from the Maastrichtian type area and New Jersey. Geol. Mijnb., 78, 281-300.
Mulder E., Jagt J., Kuypers M., Peeters H. \& Rompen P. (1998). - Stratigraphic distribution of Late Cretaceous marine and terrestrial reptiles from the Maastrichtian type area. - Oryctos, 1, 55-64.

Olsson R. K., Miller K. G., Browning J. V., Habib D. \& Sugarman P. (1997). - Ejecta layer at the Cretaceous-Tertiary boundary, Bass River, New Jersey (Ocean Drilling Program Leg 174AX). - Geology, 25, 759-762.

Olsson R. K., Miller K. G., Browning J.V., Wright J. D. \& Cramer B. S. (2002). - Sequence stratigraphy and sea-level change across the Cretaceous-Tertiary boundary on the New Jersey passive margin. In: C. Koeberl \& K. G. Mackleod, Eds., Catastrophic events and mass extinctions: Impacts and beyond. - Geol. Soc. Amer. Sp. Paper, 356, 97-108.

Polcyn M.J., Jacobs L.L, Schulp A.S., Mateus O. \& Lindgren J. (2010). An update on mosasaurs of Angola. - Third Mosasaur meeting: schedule, abstracts and field guide, Museum National d'Histoire Naturelle, Paris, France, 18-22 May, 2010, 17.

Russell D. (1967). - Systematics and morphology of American mosasaurs. - Yale University Peabody Museum of Natural History Bull., 25, 240 p.

Sullivan R. (1989). - A reassessment of reptilian diversity across the Cretaceous-Tertiary boundary. - Contrib. Science, Natural History Museum of Los Angeles County, 391, 1-26. 